\title{
Bioremediation of oil-contaminated water by bacterial consortium immobilized on environment-friendly biocarriers
}

\author{
Original Farag A. Samhan, Mohamed A. Elliethy, Bahaa A. Hemdan, Marwa Youssef, \\ Article \\ Gamila E. El-Taweel
}

Water Pollution Research Department, National Research Centre, Giza, Egypt.

\begin{abstract}
Background: Accidental oil spill in the Nile River represents a public health concern in Egypt. Bioremediation of oil-contaminated water is efficiently competitive and economically effective compared with mechanical and chemical methods.

Aim: The current study aimed to; i) assess using environment-friendly materials as carriers for immobilizing oil-degrading bacteria and ii) evaluate applying these biocarriers for removal of oil from water in a batch experiment.

Materials and Methods: Four bacterial strains Pseudomonas aeruginosa, Cronobacter sakazakii (recently named Enterobacter sakazakii), Klebsiella oxytoca and Bordetella bronchispetica were immobilized on grinded corn qgualh, Egyptian loofah, palm leaf raffia and sponge. Immobilizing bacterial consortium was carried out by incubating bacteria with carriers at $37^{\circ} \mathrm{C}$ with shaking at $120 \mathrm{rpm}$ for three days. Biofilm formed on biocarriers was checked using scanning electron microscopy. Biocarriers with immobilized bacterial consortium were used for removal of oil. Experiments were carried out in flasks each containing $100 \mathrm{ml}$ of mineral salt broth fortified with $1 \mathrm{~g} / 1$ light crude oil. Flasks were incubated at $37^{\circ} \mathrm{C}$ with shaking at $120 \mathrm{rpm}$ for nine weeks. Total viable bacterial count and oil and grease were determined weekly. Results: Oil and grease measurements showed a significant removal that reached 68.3, 71.5, 77.7 and 81\% for grinded corn qgualh, Egyptian loofah, palm leaf raffia and sponge respectively. Flasks inoculated with sponge biocarriers showed rapid oil removal compared with other biocarriers. Gas chromatography-mass spectrometry (GC-MS) showed a percentage removal that reached $87 \%$ for compounds $\mathrm{C} 11$ to $\mathrm{C} 32$ in case of sponge carrier.

Conclusion: Immobilizing bacteria on biocarriers showed a good biofilm formation. Immobilized bacterial consortium showed rapid and efficient oil removal in bioremediation processes. Sponge showed dense bacterial colonization and consequently biofilm formation compared with other biocarriers.
\end{abstract}

Received: 05 October 2016, Accepted: 26 August 2017

Key Words: Biodegradation, environment-friendly biocarrier, immobilization, light crude oil.

Corresponding Author: Farag A. Samhan, Associate Professor, Water Pollution Research Department, National Research Centre, Giza, Egypt, Tel.: +20 233371 362, E-mail: sameissa@msu.edu, faragsamhan@gmail.com

ISSN: 0013-2446, Vol. 92, No.1

\section{INTRODUCTION}

Oil contamination has become a global public health problem especially in developing countries. In Egypt, Nile River Transport, Nile Cruise tourism, and oil distribution centers located along River Nile have deteriorated its water quality due to direct or indirect leakage of different effluents into the water body ${ }^{[1,2]}$. This is due to accidental oil spill which might be derived from failure to control barges, tankers, and boats activities in the Nile River ${ }^{[3,4]}$.

Petroleum hydrocarbons are one of the common toxic organic chemicals being introduced into river streams ${ }^{[5]}$. Mechanical and chemical methods are densely used for treating petroleum-contaminated water, but these methods are generally expensive and have limited effectiveness ${ }^{[6,7]}$. Bioremediation of oil-contaminated water is a promising technology due to its economic and environmental effectiveness ${ }^{[4,8]}$. Isolation of highly potential bacterial strains from oil-contaminated environment and determining the optimum factors controlling its vitality are factors preceding the biodegradation process ${ }^{[8,9]}$. Oil removal in a crude, oil-contaminated water could be enhanced by immobilization of hydrocarbon-degrading bacteria on biocarriers ${ }^{[10]}$. Biocarriers provide large surface area and strong adsorption capability. In addition, they improve oxygen diffusion and enhance dehydrogenase activity ${ }^{[5]}$. In Egypt, many agricultural residues can be used as biocarriers $^{[11]}$. Examples include Egyptian loofah (Luffa cylindrica $)^{[6]}$, palm leaf raffia, corn qgualh, and used sponge ${ }^{[5]}$. These carrier materials are environment-friendly (nontoxic and nonpolluting materials) and economic ${ }^{[12]}$. Maintaining high biomass of bacterial populations on biocarriers is a key point for bioremediation ${ }^{[10]}$. Besides, 
immobilization is crucial to improve the survival and retention of bacterial cells ${ }^{[13]}$. Immobilized cell systems provide high biomass and cell reuse, reducing the costly processes of cell recovery and cell recycle ${ }^{[14,15]}$. In addition, they have high resistance to toxic chemicals, $\mathrm{pH}$ and temperature variation, solvents, and heavy metals and they show a decline in maturation time for some products ${ }^{[5,14]}$.

The aim of the current study was to use economical and environment-friendly biocarriers for immobilizing consortium of bacterial isolates to remediate oilcontaminated water in a running batch reactor.

\section{MATERIALS AND METHODS}

\section{Crude oil sample}

Light crude oil was provided from the Egyptian Institute for Petroleum Research, Ministry of Scientific Research and Technology, Egypt.

\section{Sampling collection sites}

Forty water samples were collected from six sites along the Nile River in the Cairo segment (seven samples at El-Hawamdia Sugar factory discharge, seven samples at El-Maasara Bridge, seven samples at El-Hawamdia Bridge, seven samples at Masr El-Qadima bus station, six samples at Cairo University bus station, and six samples at Nadi El-Tagdif). Nine sediment samples were collected from three sites along Ismailia Canal as follows. Mosturod: three samples before discharge of ExxonMobil Company, (Khanka, Qlyubia, Egypt), three samples after discharge of ExxonMobil Company (Khanka, Qlyubia, Egypt) and three samples after discharge of Abouzabal Chemical Fertilizer Factory (Khanka, Qalyubia, Egypt). The samples were collected during the period from October 2014 to January 2015. Chemical screening of aliphatic and aromatic hydrocarbon pollutants and bacteriological examination of the samples were carried out according to APHA ${ }^{[16]}$.

\section{Isolation, screening, and identification of light- crude oil-degrading bacteria}

Oil-degrading bacteria were isolated as described by Lin et al $^{\left[{ }^{14]}\right.}$ It was conducted as follows: $10 \mathrm{~g}$ of sediment samples and $1 \mathrm{~g}$ of crude oil were coincubated in $100 \mathrm{ml}$ mineral salt broth $\left(7.01 \mathrm{mmol} / \mathrm{K}_{2} \mathrm{HPO}_{4}, 2.94 \mathrm{mmol} / \mathrm{l}\right.$ $\mathrm{KH}_{2} \mathrm{PO}_{4}, 0.81 \mathrm{mmol} / 1 \mathrm{MgSO}_{4} 7 \mathrm{H}_{2} \mathrm{O}, 0.18 \mathrm{mmol} / \mathrm{l} \mathrm{CaCl}$, $1.71 \mathrm{mmol} / 1 \mathrm{NaCl}$ ) for 7 days under shaking at $180 \mathrm{rpm}$ at $30^{\circ} \mathrm{C}$. One milliliter of the liquid culture was diluted sequentially to $10^{-7}$. One milliliter aliquots of each dilution were spread onto mineral agar which was prepared by adding $1.5 \%$ agar into the mineral media. The plates were incubated at $37^{\circ} \mathrm{C}$ for $48 \mathrm{~h}$. Bacteria having the ability to use oil as carbon and energy source and consequently showing colony formation were taken as oil-degrading bacteria. They were assessed by viable cell counting. In addition, gravimetric measurement of the residual crude oil remaining in the culture medium was done at the end of incubation time.

Four bacterial strains were screened and purified from total 225 isolates during the first stage of this study ${ }^{[17]}$. The biochemical identification of bacterial isolates was carried out using Biolog GEN III, (Biolog Int., USA). Each bacterial isolate was inoculated in 94-well Microplates to analyze the phenotypic characters of each microorganism: 71-wells for carbon source utilization assays and 23-wells for chemical sensitivity assays. This test provides a phenotypic fingerprint of the microorganism that can be used to identify it at the species level.

In parallel to biochemical identification, the genetic identification was started. Slant copies were delivered to Macrogen Company (Republic of South Korea) for 16s rRNA sequencing identification. Results were provided on Sequence Scanner Software version 1.0. Sequencing products were resolved on an Applied Biosystems model 3730XL (automated DNA sequencing system Applied Biosystems, USA). The nucleotides BLAST (National Center for Biotechnology Information online program) was used to compare the identity of the strains with databases present on the GenBank.

\section{Preparation of seed and mixed culture}

A single colony was transferred from single slant cultures (48 h age) into $50 \mathrm{ml}$ aliquots of trypticase soy broth $^{[16]}$. Bacterial culture was centrifuged at $2700 \mathrm{rpm}$ and the supernatant was decanted. The sediment was washed using a buffered saline solution containing/100 ml $\left(\mathrm{Na}_{2} \mathrm{HPO}_{4}, 0.81 \mathrm{~g}, \mathrm{KH}_{2} \mathrm{PO}_{4}, 0.18 \mathrm{~g}\right)$ at $\mathrm{pH} 7.4$ two times. The cell count of each strain was diluted to reach $10^{7}$ colony forming unit per milliliter $(\mathrm{CFU} / \mathrm{ml})$. Ten milliliter from each strain suspension was taken to constitute a volume of $40 \mathrm{ml}$ bacterial consortium from the four strains.

\section{Preparation of biocarrier materials}

One gram from each biocarrier material: Egyptian loofah (Luffa cylindrica), palm leaf raffia, and sponge were prepared in symmetric size cubes (nearly one $\mathrm{cm}$ dimension). Corn qgualh was ground and $1 \mathrm{~g}$ was weighed out. Carrier materials were washed with distilled, sterile water and dried at $37^{\circ} \mathrm{C}$ for $4 \mathrm{~h}$ before being used for immobilization of bacterial strains (Fig. 1). 


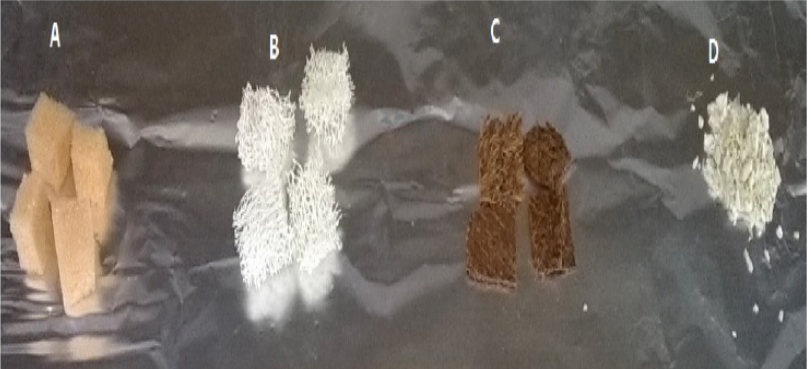

Fig. 1: Carrier materials were prepared in the form of separate pieces, A: sponge was prepared in the form of cubes, with dimensions of nearly $1 \mathrm{~cm}$ height $\times 1 \mathrm{~cm}$ width $\times 1 \mathrm{~cm}$ length, $B$ : Egyptian Loofah (Luffa cylindrica) was prepared in the form of cubes with dimensions of nearly $1 \mathrm{~cm}$ height $\times 1 \mathrm{~cm}$ width $\times 1 \mathrm{~cm}$ length, C: Palm leaf raffia was prepared in dimensions of nearly 1 $\mathrm{cm}$ width $\times 1 \mathrm{~cm}$ length, $\mathrm{D}$ : Corn qgualh was grinded in variable sizes $\approx 0.1-0.3 \mathrm{~cm}$ dimensions.

\section{Immobilization of bacterial cells}

The prepared biocarrier materials were immersed in culture flasks, each containing $150 \mathrm{ml}$ mineral salt broth. Three milliliter $\left(10^{7} \mathrm{CFU} / \mathrm{ml}\right)$ of the bacterial consortium was added to each flask. The culture flasks were incubated at $37^{\circ} \mathrm{C}$ for 3 days in a shaker at a speed of $120 \mathrm{rpm}$. At this stage, biocarriers were ready to start the biodegradation experiment after immobilizing the bacterial consortium. Immobilization (either by adhesion and/or entrapment) was checked by scanning electron microscopy (SEM).

\section{Application of immobilized bacteria for} biodegradation in a batch reactor

Sterile flasks (250 $\mathrm{ml}$ volume) each containing $150 \mathrm{ml}$ of mineral salt broth fortified with $1 \mathrm{~g}$ light crude oil were used as bioreactors. One gram from each biocarrier with immobilized bacterial consortium was transferred to each flask. Flasks were incubated at $37^{\circ} \mathrm{C}$ under shaking at $120 \mathrm{rpm}$. The experiment was carried out in two replicates for each carrier. The whole experiment was repeated three times. The maximum incubation time was 9 weeks. Counting bacterial biomass in each flask followed up the biodegradation process. Total viable bacterial count was weekly determined with the pour plate method for 9 weeks (Fig. 2) ${ }^{[16]}$.

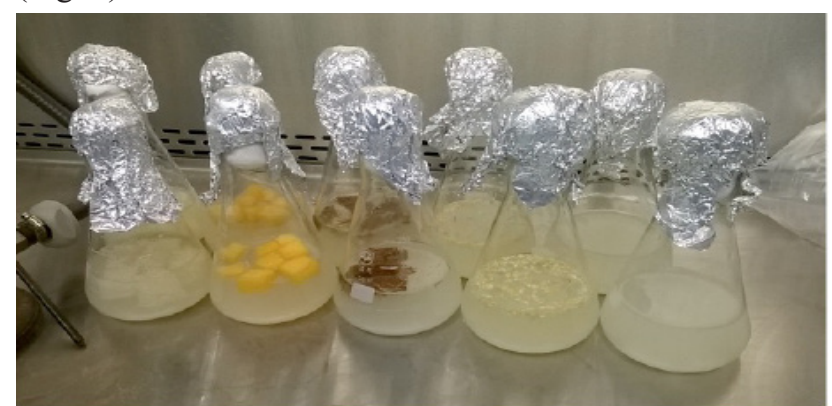

Fig. 2: Batch culture for the biocarriers immersed in mineral salt broth fortified with $1 \mathrm{gm}$ oil/1, incubation at $37^{\circ} \mathrm{C}$ and shaker $120 \mathrm{rpm}$

\section{Chemical analysis for oil and grease}

Sediment $(20 \mathrm{~g})$ and water $(30 \mathrm{ml})$ samples were transferred from the sample container. Sediment samples were weighed on an analytical balance, meshed and ground using a mortar and pestle until the sample was nearly as homogeneous as possible. Oil and grease was measured in water and sediment samples collected from the selected sampling sites according to APHA (2012) ${ }^{[16]}$.

\section{Determination of consumed hydrocarbons}

At the end of the incubation time, the residual hydrocarbons in each culture medium were extracted by using chloroform [three samples: one chloroform (Sigma, Germany)]. Samples were continuously shaken with chloroform in a separating funnel. The contents were allowed to separate, two layers were formed: a watery layer and a chloroform layer containing the residual hydrocarbons, which was left to decant and air dry (ASTM-D-2007). After chloroform evaporation, the residual hydrocarbons were weighted and the consumed hydrocarbons were calculated by subtracting the residual hydrocarbons from the original weight of hydrocarbons (control).

\section{RESULTS}

\section{Identification of bacterial strains}

A mixed culture of four strains was immobilized using different types of natural environment-friendly materials to be used for biodegradation of oil spills. The isolates were identified using Biolog GEN III and sequencing for the completion of identification ${ }^{[18]}$. Sequencing analyses for complete genome of bacterial isolates using $16 \mathrm{~S}$ rRNA reported the following bacterial strains with the matched accession numbers: Pseudomonas aeruginosa (accession number KF835840.1) with 99\% identity, Cronobacter sakazakii (recently named Enterobacter sakazakii) (accession number NR102490.1) with 96\% identity Klebsiella oxytoca KCTC 1686 (accession number NC016612.1) with 95\% identity, and Bordetella bronchispetica 253 (accession number NC019382.1) with $98 \%$ identity.

\section{Immobilization of selected strains}

Fibrous biocarrier materials of sponge, loofah, palm raffia, and ground corn qgualh were used as biocarriers in this study. The immobilizations of bacterial strains on biocarriers were shown by SEM images. Samples were investigated by SEM after coating with gold (high vacuum mode). Images for the immobilized bacterial consortium are illustrated in Figs 3-6. 

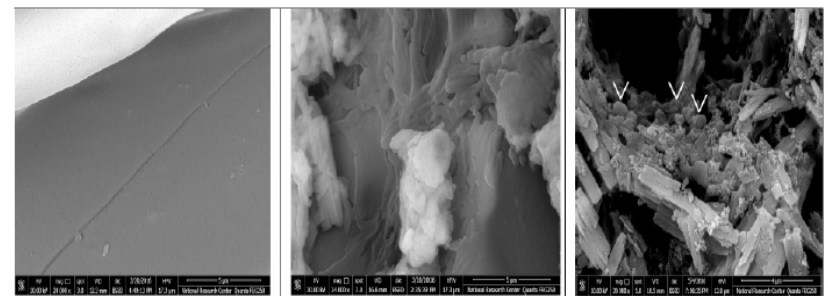

Fig. 3: SEM images for sponge carrier $(a, b$ and $c$ from left to right); a. control without any bacterial attachment (bare 5 $\mu \mathrm{m}), \mathrm{b}$. dense fresh rod-shaped biofilm and white material (exopolysacharides) (bare $5 \mu \mathrm{m}$ ), c. cocci-shaped cells (the arrow) on old sponge carrier material (bare $4 \mu \mathrm{m}$ )
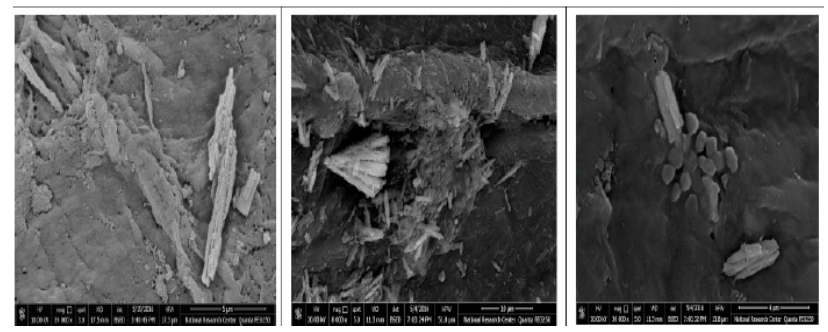

Fig. 4: SEM images of biofilm formed on Loofah biocarrier ( $a, b$ and c from left to right); a. control without bacterial attachment (bare $5 \mu \mathrm{m}$ ), b. dense continuous layer of cocci-shaped bacterial cells (bare $10 \mu \mathrm{m}$ ), c. aggregate of cocci-shaped bacterial cells supported on the biocarrier (bare $4 \mu \mathrm{m}$ )
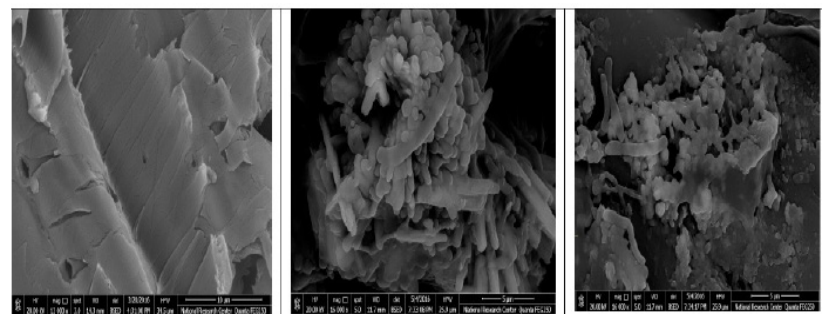

Fig. 5: SEM images of biofilm formed on palm raffia biocarrier ( $\mathrm{a}, \mathrm{b}$ and $\mathrm{c}$ from left to right); $\mathrm{a}$. control with media and no biofilm formation (bare $10 \mu \mathrm{m}$ ); b. dense and fresh biofilm of rod-shaped cells (bare $5 \mu \mathrm{m}$ ), c. film of cocci-shaped cells covered with thin layer of exopolysaccharide, and threads of exopolysaccharide to left of the image (bare $5 \mu \mathrm{m}$ )
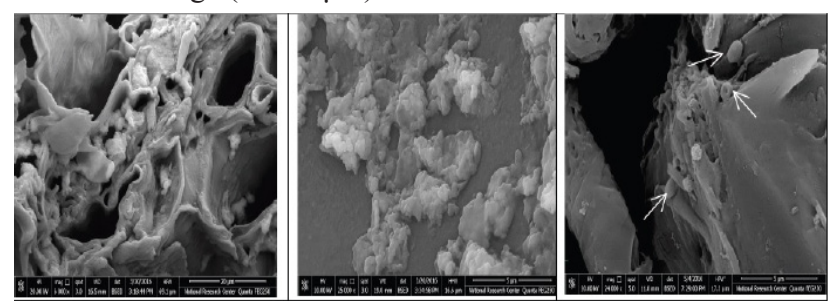

Fig. 6: SEM images of biofilm formed on grinded corn qgualh biocarrier ( $a, b$ and $\mathrm{c}$ from left to right); $\mathrm{a}$. control with media and no biofilm (bare $20 \mu \mathrm{m}$ ), b. bacterial cocci-shaped cells on surface of qgualh and exopolysaccharides (bare $5 \mu \mathrm{m}$ ), c. cocci-shaped cells attached to qgualh surface (bare $5 \mu \mathrm{m}$ )

Controls of different carriers are illustrated in Figs 3a, $4 \mathrm{a}, 5 \mathrm{a}$ and $6 \mathrm{a}$ where SEM showed no biofilm on sponge, loofah, palm raffia, and qgualh, respectively. Figure $3 \mathrm{~b}$ shows the biofilm of bacillary cells partially covered with exopolysaccharides. Figure 3c shows coccoid cells on sponge tissue. Figure $4 \mathrm{~b}$ shows dense coccoid cells of bacterial biofilm formed and attached on loofah biocarriers. Fig. 4c shows aggregate of cuboidal cells. Figure $5 \mathrm{~b}$ and $\mathrm{c}$ show sufficiently strong interaction between bacterial cells coherent on the biocarrier surfaces, and the interconnection between individual bacterial cells via extracellular polysaccharides, suggesting that the bacterial cultures were tending to form thick biofilms. Figure $6 \mathrm{~b}$ and c show coccoid cells forming biofilm attached on the ground corn qgualh surfaces. Bacterial biofilm synthesized exopolysaccharide support attachment to the biocarriers.

The changes of bacterial numbers and activity in water are shown in Figs 3-7.

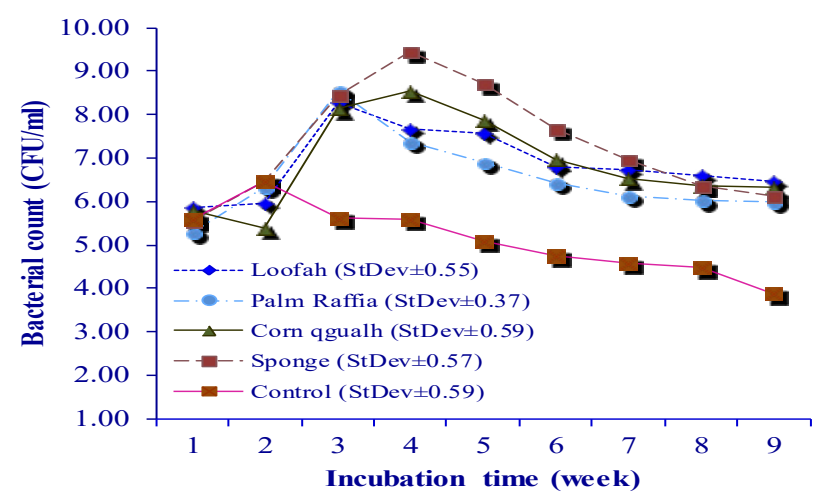

Fig. 7: Bacterial consortium count $(\mathrm{cfu} / \mathrm{ml})$ in batch flasks containing bio-carriers incubated at $37^{\circ} \mathrm{C}$ and shaken at $120 \mathrm{rpm}$, bars on each curve show the standard deviation

The number of bacteria entrapped was critical to the biodegradation effectiveness of the immobilized cells. The four different carriers were loaded with a bacterial consortium of up to $1.8 \times 10^{6} \mathrm{CFU} / \mathrm{ml}$; sponge was more effective compared with other carriers. Bacterial count increased by $2-3 \operatorname{logs}\left(1.24 \times 10^{8}-1.6 \times 10^{9} \mathrm{CFU} / \mathrm{ml}\right)$.

\section{Comparison of growth curves of bacterial consortium with and without carrier material.}

In the absence of crude oil as the sole carbon source, the growth curve of bacterial count consortium decreased from $6.0 \times 10^{6}$ to $8.0 \times 10^{2} \mathrm{CFU} / \mathrm{ml}$ within 9 weeks in the batch reactor. When comparing the control with the other carrier growth curves, results showed no growth decline for all carriers. When using sponge carrier, bacterial consortium count reached the maximum after 3 weeks. The bacterial biomass produced in the case of sponge was higher $(8 \mathrm{x}$ $10^{9} \mathrm{CFU} / \mathrm{ml}$ ) in comparison with other biocarriers. Palm leaf raffia, Egyptian loofah, and ground corn qgualh showed a bacterial count increase from $1.2 \times 10^{8}$ to $6.8 \mathrm{x}$ $10^{8} \mathrm{CFU} / \mathrm{ml}$ in a way similar to the sponge carrier (Fig. 7).

\section{Application of immobilized cells for biodegradation of hydrocarbons}

Average counts of bacterial consortia $\left(10^{7}-10^{8} \mathrm{CFU} / \mathrm{ml}\right)$ were immobilized on carriers. The trial was repeated three times and represented as log values in 
Fig. 7. Results showed that the free indigenous bacterial cultures were quickly adapted to the environment and showed rapid multiplication and increase of total microbial activity within 2-3 weeks. In the immobilized systems, bacterial isolates in the batch reactor showed similar growth kinetics of degrading microorganisms and total microbial activity.

Average start counts of the three trials were $5.7 \times 10^{5}-1.41 \times 10^{6} \mathrm{CFU} / \mathrm{ml}$. After 2-3 weeks, the consortium count has shown an increase to $7.7 \times 10^{8} \mathrm{CFU} / \mathrm{ml}$, while the control flask showed a count of $7.0 \times 10^{5}$ by the end of the third week. Counts increased gradually after the second week and reached the maximum in week 3 . This count continued for further 5 weeks, then started to decrease by one log. Results in Fig. 7 show that the highest bacterial biomass was generated in the sponge carrier followed by palm leaf raffia, loofah, and then ground corn qgualh.

The percentage degradation of the crude oil was calculated by comparison of the gas chromatography-mass spectrometry (GC-MS) analysis of the nondegraded oil (control) and the sample after incubation with bacterial consortium, carrier, and bacterial consortium immobilized on the sponge carrier (Fig. 8) for each experiment.

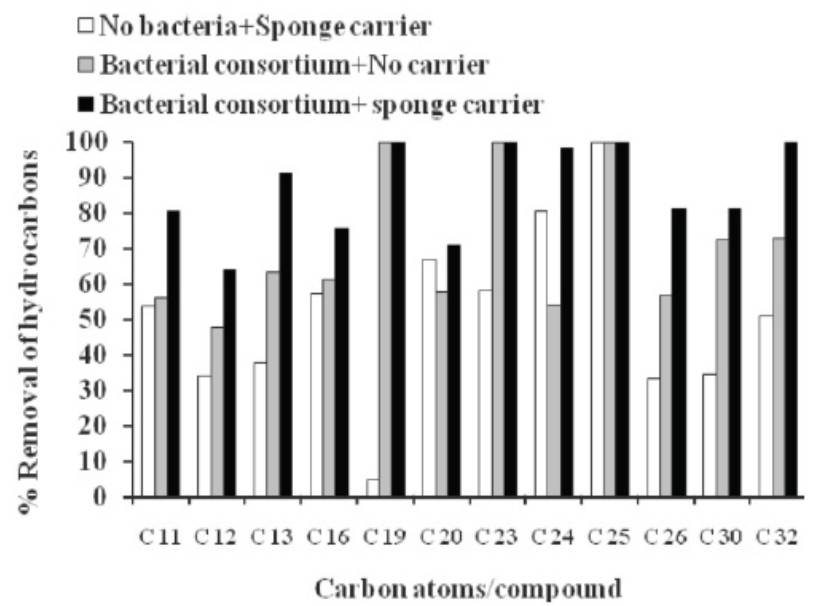

Fig. 8: Hydrocarbons removal $(\mathrm{C} 11-\mathrm{C} 32)$ by bacterial consortium immobilized on sponge carrier incubated at $37^{\circ} \mathrm{C}$ and shaken

Percentage removal of hydrocarbons was the maximum after treating the sample with the bacterial consortium immobilized on the sponge carrier. The results indicate a significant decrease of hydrocarbons C32, C25, C23, and C19 during the biodegradation process. After 9 weeks, the GC-MS results showed that immobilized bacteria were capable of removing more hydrocarbons than the suspended bacteria. Results have shown that average removal of the suspended bacteria consortium reached $70 \%$. Immobilizing bacterial consortium on sponge has increased the hydrocarbon removal (C11-C32) to $87 \%$.
In parallel to GC-MS analysis, the crude oil was measured as oil and grease concentration along the incubation time. The initial concentration in all flask reactors was adjusted to $1 \mathrm{~g} / \mathrm{l}$. The concentration of residual oil and grease was monitored biweekly for all carriers and is illustrated in Table 1. The highest removal rate was seen in the ninth week for sponge and palm leaf raffia with a removal percentage of 81 and $77.7 \%$, respectively. The rate of oil removal was detected via an increase of microbial consortium activity, time, and carrier types. The removal rate of crude oil was calculated after comparing the oil and grease concentrations in the control group and in other groups using different carriers.

Table 1: Percentage removal of oil and grease using immobilized bacterial consortium on different biocarriers

\begin{tabular}{|c|c|c|c|c|}
\hline Carrier & $\begin{array}{c}\text { Initial } \\
\text { oil conc. } \\
\text { (g/l) }\end{array}$ & $\begin{array}{c}\text { Residual } \\
\text { oil (g/l) }\end{array}$ & $\begin{array}{c}\text { Removed } \\
\text { oil (g/l) }\end{array}$ & $\begin{array}{l}\% \text { of } \\
\text { removal }\end{array}$ \\
\hline $\begin{array}{l}\text { Control (no } \\
\text { carrier) }\end{array}$ & 1 & 0.99 & 0.01 & $1^{*}$ \\
\hline Loofah & 1 & 0.285 & 0.715 & 71.5 \\
\hline $\begin{array}{l}\text { Palm leaf } \\
\text { raffia }\end{array}$ & 1 & 0.223 & 0.777 & 77.7 \\
\hline $\begin{array}{l}\text { Grinded corn } \\
\text { qgualh }\end{array}$ & 1 & 0.317 & 0.683 & 68.3 \\
\hline Sponge & 1 & 0.19 & 0.810 & 81 \\
\hline \multicolumn{5}{|c|}{$\begin{array}{l}\text { *Non-actual removal percentage, it shows trace of oil adhered on } \\
\text { the inner walls of the flasks }\end{array}$} \\
\hline \multicolumn{5}{|c|}{ DISCUSSION } \\
\hline
\end{tabular}

In this study, the four identified isolates $[P$. aeruginosa (accession number KF835840.1)], C. sakazakii (recently named $E$. sakazakii) (accession number NR102490.1), $K$. oxytoca KCTC 1686 and B. bronchispetica 253 using 16s rRNA were multiplied and immobilized on environmentfriendly carriers for remediation of oil-contaminated water. Several studies found that $P$. aeruginosa had superiority for crude oil biodegradation ${ }^{[15,17,19]}$. This might be due to their metabolic diversity, abundance in microbial communities, and their resistance to chemical remediation agents ${ }^{[17,19]}$. Many studies have mentioned that E. sakazakii and $K$. oxytoca have the ability to degrade the crude oil and can be used for bioremediation purposes ${ }^{[3,15]}$. In the present study, we isolated $B$. bronchispetica from Nile water with the ability to degrade crude oil. One disadvantage of using $B$. bronchiseptica for biodegrading oil as it was encountered both as a commensal and a cause of respiratory tract disease in many wild and domestic animals ${ }^{[20]}$. 
The selection of a carrier is important for using in immobilization. An ideal carrier should be nontoxic, nonpolluting, nonbiodegradable, having high cell mass loading capacity, biologically and chemically stable, having a long shelf life, low cost, diffusible by bacteria, easy to handle from media, and easy to regenerate ${ }^{[5,15]}$. In this study, loofah, palm leaf raffia, and corn-ground qgualh were selected as carriers from agricultural residues, in parallel with the sponge material. The suitability of carriers for immobilization of the bacterial consortium was investigated on weekly intervals. After 3 weeks of incubation, the immobilization of the bacterial consortium on carriers was shown using a SEM. SEM showed different shapes of the biofilm formed and attached on the surface of carriers, in addition to the production of exopolysaccharides $^{[21,22]}$.

The sponge, loofah, palm leaf raffia, and corn-ground qgualh carriers can serve as a suitable material for immobilizing bacteria, because they have better chemical and thermal stability ${ }^{[23]}$. For immobilization of bacteria, the sponge carrier supports the higher biomass density and microbial activity yield than the other three carriers. The maximum growth count of mixed culture strains immobilized on sponge averaged as $8 \times 10^{9} \mathrm{CFU} / \mathrm{ml}$. This might be attributed to the greater mass transfer of the substrate (and oxygen) between the bulk solution and the bacteria immobilized on carrier ${ }^{[19,24,25]}$.

Degrading bacterial consortium population and activity dropped and reached equilibrium in all treatments by the fourth and the fifth week. This was possibly due to the fact that the bulk of labile hydrocarbons and other nutrients had been consumed before 4 weeks ${ }^{[9,26]}$. In addition, the productions of toxic intermediates were likely to have an inhibitory influence upon bacterial consortium by the end of the third week ${ }^{[9,27]}$.

Biofilms are superficial growths constituting of aerobic and anaerobic bacteria arranged in multiple layers embedded in hydrated matrices ${ }^{[28]}$. Bacterial immobilization could occur via adsorption, covalent binding, entrapment, and encapsulation ${ }^{[5,22]}$. Excellent degradation is enhanced by high immobilization efficiency of bacterial cells onto the carrier material and the high affinity between the hydrophobic immobilization material and the substrates ${ }^{[5,22]}$. The availability of the substrates for bacterial cells and cohesive interaction between the substrates and the immobilized cells could accelerate the degradation rate $^{[29]}$. Hsu et al. ${ }^{[21]}$ stated that immobilization by adsorption is mild, quick, simple, and economically advantageous, since there is no need for chemical additives, in addition to easy performance of the process with possible reuse of the carrier for other treatments. It has the advantage of enzyme leak from the biofilm layer adsorbed onto the carrier to the suspending oil ${ }^{[21]}$. Moreover, cell immobilization by adsorption provides a direct contact between nutrients and immobilized cells. Absorptivity and stability of biocarriers are two major criteria for the selection of a suitable supporting material ${ }^{[21]}$. Finally, the major advantages of an adsorption system for water pollution control are less investment in terms of initial cost and ease of operation ${ }^{[30]}$. High-rate bacterial growth in carriers especially in sponge could be due to the sponge material which accelerates the oxygen transfer and provides protection and a favorable niche for bacterial consortium to utilize the hydrocarbons ${ }^{[31]}$. Also, the growth of the consortium bacterial strains was highest with the sponge carrier, showing its optimistic supporting properties ${ }^{[23]}$. Some compounds in petroleum can be toxic above a certain concentration $^{[4]}$, inhibiting the metabolism of the microorganism; this explains the results we obtained for control flasks.

In this study, when applying both free and immobilized cells, GC-MS showed that the removal of crude oil from contaminated water increased by the application of hydrocarbon-degrading bacteria immobilized on the carrier $^{[9]}$. This was proved via the difference in count found between control flasks and other flasks ${ }^{[28]}$. Also, at the early stage, bacterial growth and replication within the matrix may release some bacteria to the surrounding environment ${ }^{[28]}$, resulting in low degrading bacterial count and activity in the reactor. After 2-3 weeks both bacterial count and activity increased ${ }^{[32]}$ resulting from both massive cell releases associating with oil degradation and their subsequent growth in the batch reactor ${ }^{[6]}$. In this context, the biocarrier like sponge, loofah ${ }^{[23]}$ provides a large surface area and strong adsorption capability. Tissue structure of palm raffia and ground qgualh provides an internal area to entrap the bacterial cells. In addition, it improves oxygen diffusion and enhances dehydrogenase production, thus reducing the toxic effect of petroleum compounds. Wiesel et al. ${ }^{[29]}$ reported that a mixed immobilized bacterial culture exhibited good growth, and demonstrated equivalent degradation potential of polycyclic aromatic hydrocarbons compared with freely suspended cells ${ }^{[29]}$.

The hydrophilic properties of sponge fibers and oleophilic characters allowed the contact between the crude oil particles with the immobilized bacterial cells $^{[5,33]}$. This combination facilitates more exposure of the absorbed oil to the immobilized bacterial consortium. The adherence of oil to the bacterial consortium coated biocarriers is a simple way to boost the substrate uptake speed $^{[15]}$. The high rate growth of bacterial consortium in carriers especially sponge could be due to the acceleration of oxygen transfer, providing protection and a favorable niche for bacterial consortium to utilize hydrocarbons ${ }^{[27]}$.

In this study, after applying the immobilized consortium for biodegrading light crude oil, the mixed consortium of bacterial strains degraded $81 \%$ of oil using the sponge carrier, followed by $77 \%$ in case of palm leaf raffia carrier. Loofah and ground corn qgualh showed 71.5 and $68.3 \%$ degradation, respectively. This comes in parallel with Wang et al. ${ }^{[32]}$ who found that the consortium bacteria degraded a maximum of $77 \%$ crude oil followed 
by $69 \%$ by Pseudomonas spp. BPS $1-8,64 \%$ by Bacillus spp. ISS1-7, 45\% by Pseudomonas spp. HPS2-5, and $41 \%$ by Gorynebacterium spp. BPS2-6 at $1 \%$ crude oil concentration $^{[27]}$.

In our study, we used a mixed culture of four selected strains for the biodegradation of light crude oil for the synergistic mechanism resulting from interaction of consortium bacteria with their diverse enzymatic activities under suitable conditions ${ }^{[34]}$. It is possible that each species of the consortium was able to remove the toxic metabolites that may hinder the activity of the other strains; consequently they assemble an integrative simple process to remove oil ${ }^{[35]}$. Loofah is a good biocarrier for bacterial strains and effective natural biosorbent for oil spills $^{[3,36]}$. However, in a trial to apply fed-batch cultures, a bioreactor was used to immobilize 75.67 and $73.83 \%$ of aliphatic and aromatic hydrocarbons, respectively; cells on loofah were repeatedly used to degrade diesel oil ${ }^{[23]}$. A decrease in degradation capacity was reported and could be the result of intercellular oxygen and nutrient competition commonly associated with high cell concentrations.

\section{CONCLUSION}

Palm leaf raffia, sponge, loofah and ground corn qgualh can serve as suitable materials for immobilizing bacteria. For this purpose, sponge carrier supports a higher biomass density and microbial activity yield than palm leaf raffia, loofah, and ground corn qgualh carriers.

P. aeruginosa, C. sakazakii (recently named $E$. sakazakii), K. oxytoca, and B. bronchispetica have shown a high ability for utilizing oil as carbon source, but $B$. bronchiseptica is not recommended for biodegrading oil because it is encountered as a cause of respiratory tract disease in many wild and domestic animals.

\section{ACKNOWLEDGEMENT}

The authors acknowledge that this study was carried out as part of the second stage of the research project number 10130302 funded from the National Research Centre, Egypt.

\section{CONFLICT OF INTEREST}

There are no conflicts of interest.

\section{REFERENCES}

1. Mahmoud DAR, Refaat HW, Abdel-fattah AF, Mahdy EME, Shousha G. Novel application of Luffa cylindrica in production of fructose. Aust J Basic Appl Sci 2011; 5:2127-2137.

2. Badawy MI, Emababy MA. Distribution of polycyclic aromatic hydrocarbons in drinking water in Egypt.
Desalination 2010; 251:34-40.

3. Ewida AYI. Oil Spills: impact on water quality and microbial community on the Nile River, Egypt. International J Environment 2014; 3:192-198.

4. Gentili AR, Cubitto MA, Ferrero M, Rodriguéz MS Bioremediation of crude oil polluted seawater by a hydrocarbon-degrading bacterial strain immobilized on chitin and chitosan flakes. Int Biodeterior Biodegradation 2006; 57:222-228.

5. BayatZ, Hassanshahian M, Cappello S. Immobilization of microbes for bioremediation of crude oil polluted environments: a mini review. Open Microbiol J 2015; 9:48-54.

6. Boynard CA, D'Almeida JRM. Water absorption by sponge gourd (Luffa cylindrica) -polyester composite materials. J Mater Sci Lett 1999; 8:1789-1791.

7. Obayori OS, Adebusoye SA, Adewale AO, Oyetibo GO, Oluyemi OO, Amokun RA, et al. Differential degradation of crude oil (Bonny Light) by four Pseudomonas strains. J Environ Sci $2009 ; 21: 243-248$.

8. Head IM, Jones DM, Röling WFM. Marine microorganisms make a meal of oil. Nat Rev Microbiol 2006; 4:173-182.

9. Sihag S, Pathak H, Jaroli DP. Factors affecting the rate of biodegradation of polyaromatic hydrocarbons. Int J Pure Appl Biosci 2014; 2:185-202.

10. Moreno-garrido I. Microalgae immobilization: current techniques and uses. Bioresour Technol 2008; 99:3949-3964.

11. Kostakioti M, Hadjifrangiskou M, Hultgren SJ. Bacterial biofilms: development, dispersal, and therapeutic strategies in the dawn of the post antibiotic era. Cold Spring Harb Perspect Med 2013; 3:1-23.

12. Cai M, Yao J, Yang H, Wang R, Masakorala K. Aerobic biodegradation process of petroleum and pathway of main compounds in water flooding well of Dagang oil field. Bioresour Technol 2013; 144:100-106.

13. Zacheus OM, Iivanainen EK, Nissinen TK, Lehtola MJ, Martikainen PJ. Bacterial biofilm formation on polyvinyl chloride, polyethylene and stainless steel exposed to ozonated water. Water Res 2000; 34:63-70.

14. Lin M, Liu Y, Chen W, Wang H, Hu X. Use of bacteriaimmobilized cotton fibers to absorb and degrade crude oil. Int Biodeterior Biodegradation 2014; 88:8-12. 
15. Chettri B, Mukherjee A, Langpoklakpam JS, Chattopadhyay D, Singh AK. Kinetics of nutrient enhanced crude oil degradation by Pseudomonas aeruginosa AKS1 and Bacillus sp. AKS2 isolated from Guwahati refinery, India. Environ Pollut 2016; 216:548-558.

16. American Public Health Association (APHA), American Water Works Association(AWWA), Water Environment Federation, E.W. Rice, R.B. Baird, A.D. Eaton, L. S. Clesceri (2012) Standard Methods for the Examination of Water and Wastewater, 22nd ed. E.W. Rice, R.B. Baird, A.D. Eaton, and L.S. Clesceri (eds). New York: American Public Health Association.

17. Das K, Mukherjee AK. Crude petroleum-oil biodegradation efficiency of Bacillus subtilis and Pseudomonas aeruginosa strains isolated from a petroleum-oil contaminated soil from North-East India. Bioresour Technol 2007; 98:1339-1345.

18. El-Liethy MA, Hemdan BA, Samhan FA, Ali SS, El-Taweel GE. Optimizing conditions for crude oil degrading bacterial consortium isolated from aquatic environment. Poll Res 2017; 36:197-204

19. Nie $M$, Nie $H$, He $M$, Lin $Y$, Wang $L$, Jin P, et al. Immobilization of biofilms of Pseudomonas aeruginosa NY3 and their application in the removal of hydrocarbons from highly concentrated oil-containing wastewater on the laboratory scale. J Environ Manage 2016; 173:34-40.

20. Liu B, Ju M, Liu J, Wu W, Li X. Isolation, identification, and crude oil degradation characteristics of a hightemperature, hydrocarbon-degrading strain. Mar Pollut Bull 2016; 106:301-307.

21. Hsu CH, Chu YF, Argin-Soysal S, Hahm TS, Lo YM. Effects of surface characteristics and xanthan polymers on the immobilization of Xanthomonas campestris to fibrous matrices. J Food Sci 2004; 69:441-448.

22. Cassidy MB, Lee H, Trevors JT. Environmental applications of immobilized microbial cells: a review. J Ind Microbiol. 1996; 16:79-101.

23. Maliji D, Olama Z, Holail H. Environmental studies on the microbial degradation of oil hydrocarbons and its application in Lebanese oil polluted coastal and marine ecosystem. Int J Curr Microbiol Appl Sci $2013 ; 2: 1-18$.

24. El Mahdi AM, Aziz HA, AmrSSA, Sh N, Nassar EHN. Isolation and characterization of Pseudomonas $s p$. NAF1 and its application in biodegradation of crude oil. Environ Earth Sci 2016; 75:1-11.
25. Santisi S, Cappello S, Catalfamo M, Mancini G, Hassanshahian M, Genovese L, et al. Biodegradation of crude oil by individual bacterial strains and a mixed bacterial consortium. Braz J Microbiol 2015; 387:377-387.

26. Ramírez H, Escalante-Espinosaa E Favela-Torresb E Gutierrez-Rojasb M Ramírez-Saad H. Design of bacterial defined mixed cultures for biodegradation of specific crude oil fractions, using population dynamics analysis by DGGE. Int Biodeterior Biodegradation 2008; 62:21-30.

27. Wang Q. Potential approaches to improving biodegradation of hydrocarbons for bioremediation of crude oil pollution. J Environ Prot 2011; 2:47-55.

28. Xu N, Bao M, Sun P, Li Y. Bioresource technology study on bioadsorption and biodegradation of petroleum hydrocarbons by a microbial consortium. Bioresour Technol 2013; 149:22-30.

29. Wiesel I, Wübker SM, Rehm HJ. Degradation of polycyclic aromatic hydrocarbons by an immobilized mixed bacterial culture. Appl Microbiol Biotechnol 1993; 39:110-116.

30. Nordin NI, Ariffin H, Andou Y, Hassan MA, Shirai Y, Nishida $\mathrm{H}$, et al. Modification of oil palm mesocarp fiber characteristics using superheated steam treatment. Molecules 2013; 18: 9132-9146.

31. Ng YF, Ge L, Chan WK, Tan SN, Yong JWH, Tan TTY. An environmentally friendly approach to treat oil spill: investigating the biodegradation of petrodiesel in the presence of different biodiesels. Fuel 2015; 139:523-528.

32. Wang $\mathrm{ZY}, \mathrm{Xu} \mathrm{Y}$, Wang HY, Zhao J, Gao DM, Li FM, et al. Biodegradation of crude oil in contaminated soils by free and immobilized microorganisms. Pedosphere 2012; 22:717-725.

33. Chibata I, Tosa T. Immobilized microbial cells and their applications. Trends Biochem Sci 1980; 5:88-90.

34. Kanchana N. Removal of Congo Red from aqueous solution by waste Banana Pith. Pertanika J Sci Technol $1993 ; 1: 33-42$.

35. Salleh AB, Ghazali FM, Abd Rahman RNZ, Basri M. Bioremediation of petroleum hydrocarbon pollution. Indian J Biotechnol 2003; 2:411-425.

36. Bazot S, Lebeau T. Effect of immobilization of a bacterial consortium on diuron dissipation and community dynamics. Bioresour Technol 2009; 100:4257-4761. 